\title{
Stability improvement of photovoltaic performance in antimony sulfide-based hybrid solar cells
}

\section{$\operatorname{AUTHOR}(\mathrm{S})$ :}

Hayakawa, Akinobu; Yukawa, Mayumi; Sagawa, Takashi

\section{CITATION:}

Hayakawa, Akinobu ...[et al]. Stability improvement of photovoltaic performance in antimony sulfide-based hybrid solar cells. ECS Journal of Solid State Science and Technology 2017, 6(4): Q35-Q38

ISSUE DATE:

2017-02-03

URL:

http://hdl.handle.net/2433/235558

\section{RIGHT:}

(c) The Author(s) 2017. Published by ECS. This is an open access article distributed under the terms of the Creative Commons Attribution 4.0 License (CC BY, http://creativecommons.org/licenses/by/4.0/), which permits unrestricted reuse of the work in any medium, provided the original work is properly cited. 


\title{
Stability Improvement of Photovoltaic Performance in Antimony Sulfide-Based Hybrid Solar Cells
}

\author{
Akinobu Hayakawa, ${ }^{\text {a,b }}$ Mayumi Yukawa, ${ }^{\text {a,b }}$ and Takashi Sagawa ${ }^{a, *, z}$ \\ ${ }^{a}$ Graduate School of Energy Science, Kyoto University, Kyoto 606-8501, Japan \\ ${ }^{b}$ Sekisui Chemical Co., Ltd., Shimamoto, Osaka 618-0021, Japan
}

$\mathrm{Sb}_{2} \mathrm{~S}_{3}$-based hybrid solar cells were prepared in the combination with electron transporting layer of $\mathrm{TiO}_{2}$ or $\mathrm{ZnO}$ nanoparticles in addition to poly(3-hexylthiophene)-2,5-diyl/(3, 4-ethylenedioxythiophene): poly(styrene sulfonate), zinc phthalocyanine (ZnPc), or $\mathrm{MoO}_{3}$ for hole transporting layer. Photovoltaic performance and durability of the hybrid solar cells were compared each other with or without encapsulation by using glass and UV cutoff film. Among these hybrid solar cells, it was found that a combination of glass-ITO/TiO $2 / \mathrm{Sb}_{2} \mathrm{~S}_{3} / \mathrm{ZnPC} / \mathrm{Au}$ encapsulated with glass and $\mathrm{UV}$ cut filter has the highest durability with keeping the relative power conversion efficiency of $90 \%$ through the stability test under 1 sun at $63^{\circ} \mathrm{C}$ at a relative humidity of $50 \%$ for $1,500 \mathrm{~h}$.

(C) The Author(s) 2017. Published by ECS. This is an open access article distributed under the terms of the Creative Commons Attribution 4.0 License (CC BY, http://creativecommons.org/licenses/by/4.0/), which permits unrestricted reuse of the work in any medium, provided the original work is properly cited. [DOI: 10.1149/2.0101704jss] All rights reserved.

(cc) BY

Manuscript submitted November 21, 2016; revised manuscript received January 3, 2017. Published February 3, 2017. This was Paper 804 presented at the San Diego, California, Meeting of the Society, May 29- June 2, 2016.

Various materials such as antimony sulfide $\left(\mathrm{Sb}_{2} \mathrm{~S}_{3}\right),{ }^{1-4}$ antimony selenide, ${ }^{5}$ lead sulfide, ${ }^{6}$ cadmium selenide, ${ }^{7}$ lead-halogen perovskite $^{8-10}$ have recently been applied for organic-inorganic hybrid solar cells. Among these materials, $\mathrm{Sb}_{2} \mathrm{~S}_{3}$ has much attraction for photovoltaics in terms of appropriate bandgap, high absorption coefficient, low toxicity, and abundance. ${ }^{11} \mathrm{Sb}_{2} \mathrm{~S}_{3}$ has been prepared by chemical bath deposition, ${ }^{1-4}$ atomic layer deposition, ${ }^{12}$ complexdecomposition method, ${ }^{13}$ and so on and applied as the thin film for solar cell, which has been attained the power conversion efficiency $(P C E)$ of $7.5 \% .^{4}$ Although $\mathrm{Sb}_{2} \mathrm{~S}_{3}$-based solar cell seems to be stable in air, ${ }^{1,14}$ stability test under the accelerated conditions has not yet been reported. In addition, various materials such as $\mathrm{TiO}_{2},{ }^{1} \mathrm{ZnO},{ }^{15-18}$ or $\mathrm{SnO}_{2}{ }^{19}$ have been utilized as an electron transporting layer (ETL) and polythiophenes, ${ }^{1-4} 2,2^{\prime}, 7,7^{\prime}$-tetrakis $(N, N$ di- $p$-methoxyphenylamine)-9,9'-spirobifluorene, ${ }^{20} \mathrm{ZnPc}, \mathrm{CuSCN},{ }^{21}$ $\mathrm{MoO}_{3},{ }^{22}$ or $\mathrm{NiO}^{23}$ have been used as a hole transporting layer (HTL) of the $\mathrm{Sb}_{2} \mathrm{~S}_{3}$ based solar cells, however, optimization of the combinations of ETL and HTL in terms of the durability has also not yet been explored. In this context, we prepared $\mathrm{Sb}_{2} \mathrm{~S}_{3}$-based solar cells with $\mathrm{TiO}_{2}$ or $\mathrm{ZnO}$ nanoparticles for ETL in addition to poly(3-hexylthiophene)2,5-diyl (P3HT)/ (3, 4-ethylenedioxythiophene):poly(styrene sulfonate) (PEDOT: PSS), ZnPc, or $\mathrm{MoO}_{3}$ for $\mathrm{HTL}$ and compared their photovoltaic properties with encapsulation by using glass and UV cutoff films under JIS C8938 conditions of 1 sun at $63^{\circ} \mathrm{C}$ at a relative humidity (RH) of $50 \%$.

\section{Experimental}

Preparation of $\mathrm{TiO}_{2}$ nanoparticle.-A $14.7 \mathrm{~g}$ of $\mathrm{TiO}_{2}$ powder $\mathrm{P}$ 90 (Degussa, Evonic Japan Co., Ltd.) was dispersed in $62.3 \mathrm{~g}$ of $95 \%$ ethanol. After addition of $439 \mathrm{~g}$ of zirconia beads $(\phi 50 \mu \mathrm{m})$, the $\mathrm{TiO}_{2}$ powder was ground with beads mill at $2000 \mathrm{rpm}$ for $2 \mathrm{~h}$. After the removal of the zirconia beads by filtration, ca. $60 \mathrm{~g}$ of $\mathrm{TiO}_{2}$ slurry was obtained. Addition of adjusted amount of ethanol into the above $\mathrm{TiO}_{2}$ sludge resulted in $6 \mathrm{wt} \% \mathrm{TiO}_{2}$-dispersed solution.

Preparation of $\mathrm{ZnO}$ nanoparticle.- $\mathrm{ZnO}$ nanoparticles were prepared according to the reported procedure ${ }^{24}$ with slight modifications. Zinc acetate dihydrate $(0.298 \mathrm{~g})$ was dissolved in methanol $(10 \mathrm{~g})$ and stirred for 3 min with heating up to $65^{\circ} \mathrm{C} .5 \mathrm{~g}$ of $3 \mathrm{wt} \% \mathrm{KOH}$ in methanol was poured into the above solution and stirred for $2.5 \mathrm{~h}$. After centrifugation at 20,000 rpm for $15 \mathrm{~min}$ and the removal of the supernatant, the crude precipitates were dispersed in $150 \mathrm{~g}$ of methanol through sonication. Thereafter, following another centrifugation at 20,000 rpm for $30 \mathrm{~min}$ and the removal of the supernatant,

*Electrochemical Society Member.

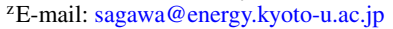

the purified precipitates were homogenously dispersed again in $0.5 \mathrm{~g}$ of $\mathrm{CHCl}_{3}$ as $\mathrm{ZnO}$ nanoparticles with an average diameter of ca. $5 \mathrm{~nm}$, as confirmed by TEM observation. Methanol was added to the above $\mathrm{ZnO}$-dispersed solution and adjusted to $2 \mathrm{wt} \%$.

Preparation of $\mathrm{Sb}_{2} \mathrm{~S}_{3}$-based hybrid solar cells.-In the preparation of solar cell devices, indium-tin oxide (ITO)-coated glass substrates (Geomatec, $10 \Omega \mathrm{cm}^{-2}$ ) were spin coated with the above dispersed solution of $\mathrm{TiO}_{2}$ or $\mathrm{ZnO}$ at 4,000 rpm followed by annealing at $300^{\circ} \mathrm{C}$ for $10 \mathrm{~min}$ with a hot-plate. $\mathrm{A} \sim 100$-nm-thick $\mathrm{Sb}_{2} \mathrm{~S}_{3}$ was deposited by thermal evaporation of the $\mathrm{Sb}_{2} \mathrm{~S}_{3}$-powder as the source under vacuum $\left(5 \times 10^{-2} \mathrm{~Pa}\right)$ onto the metal oxide layer. It was annealed at $260^{\circ} \mathrm{C}$ for 10 min ramping from $220^{\circ} \mathrm{C}$ under the reduced pressure $\left(1 \times 10^{2} \mathrm{~Pa}\right)$. After cooling down to $220^{\circ} \mathrm{C}$, HTL was subsequently coated onto the $\mathrm{Sb}_{2} \mathrm{~S}_{3}$ layer as follows. $0.5 \mathrm{wt} \% \mathrm{P} 3 \mathrm{HT}$ in chlorobenzene was spin-coated at 4,000 rpm and 3 times diluted PEDOT:PSS solution (Clevios P) with methanol was then coated at 2,500 rpm followed by annealing at $110^{\circ} \mathrm{C}$ for $10 \mathrm{~min}$. While $\mathrm{ZnPc}$ or $\mathrm{MoO}_{3}$ was deposited by thermal evaporation resulting in a 20-nm-thick layer. Thereafter Au electrode was deposited by thermal evaporation.

The solar cells obtained as described above were encapsulated with glass and epoxy resin as sealer. A cut filter (>420 nm, Asahi Spectra Co.,Ltd) was utilized for cut off the UV region of the irradiation light.

Evaluations of photovoltaic performance.-Photovoltaic characteristics were measured under AM1.5 $\left(100 \mathrm{~mW} \mathrm{~cm}^{-2}\right)$ with solar simulator of HAL-320 (Asahi Spectra Co., Ltd.) in the combination with COSMO CIV-1000F applying a bias from -0.2 to $1.0 \mathrm{~V}$ in steps of $0.05 \mathrm{~V}$ and the current density was measured just after $0.5 \mathrm{~s}$ under biased conditions.

\section{Results and Discussion}

Photovoltaic performance of the $\mathrm{Sb}_{2} \mathrm{~S}_{3}$-based hybrid solar cells for 1 d.- The photovoltaic performance of the $\mathrm{Sb}_{2} \mathrm{~S}_{3}$ based hybrid solar cells with three different HTLs consisting of glass-ITO/TiO $/ \mathrm{Sb}_{2} \mathrm{~S}_{3} / \mathrm{HTL}$ (HTL $=$ P3HT/PEDOT: PSS, ZnPc, or $\left.\mathrm{MoO}_{3}\right) / \mathrm{Au}$ were prepared and compared with each other. The current density-voltage $(J-V)$ curves of the initial (viz., freshly prepared) photovoltaic performance (solid) and the curves after $1 \mathrm{~d}$ at $63^{\circ} \mathrm{C}$ and $50 \%$ $\mathrm{RH}$ in the dark (broken) are shown in Figure 1. PCEs of ca. $3 \%$ were attained with P3HT/PEDOT: PSS and ZnPc. While PCE of $0.25 \%$ was obtained when $\mathrm{MoO}_{3}$ was applied. Since relatively higher series resistance was observed in the case of $\mathrm{MoO}_{3}$, it might be estimated that the mobility in $\mathrm{MoO}_{3}$ is lower than other HTLs and resulted in low PCE. With regard to the stability, the PCE of P3HT/PEDOT: PSS decreased slightly after $1 \mathrm{~d}$ at $63^{\circ} \mathrm{C}$ and $50 \% \mathrm{RH}$ even when there was 

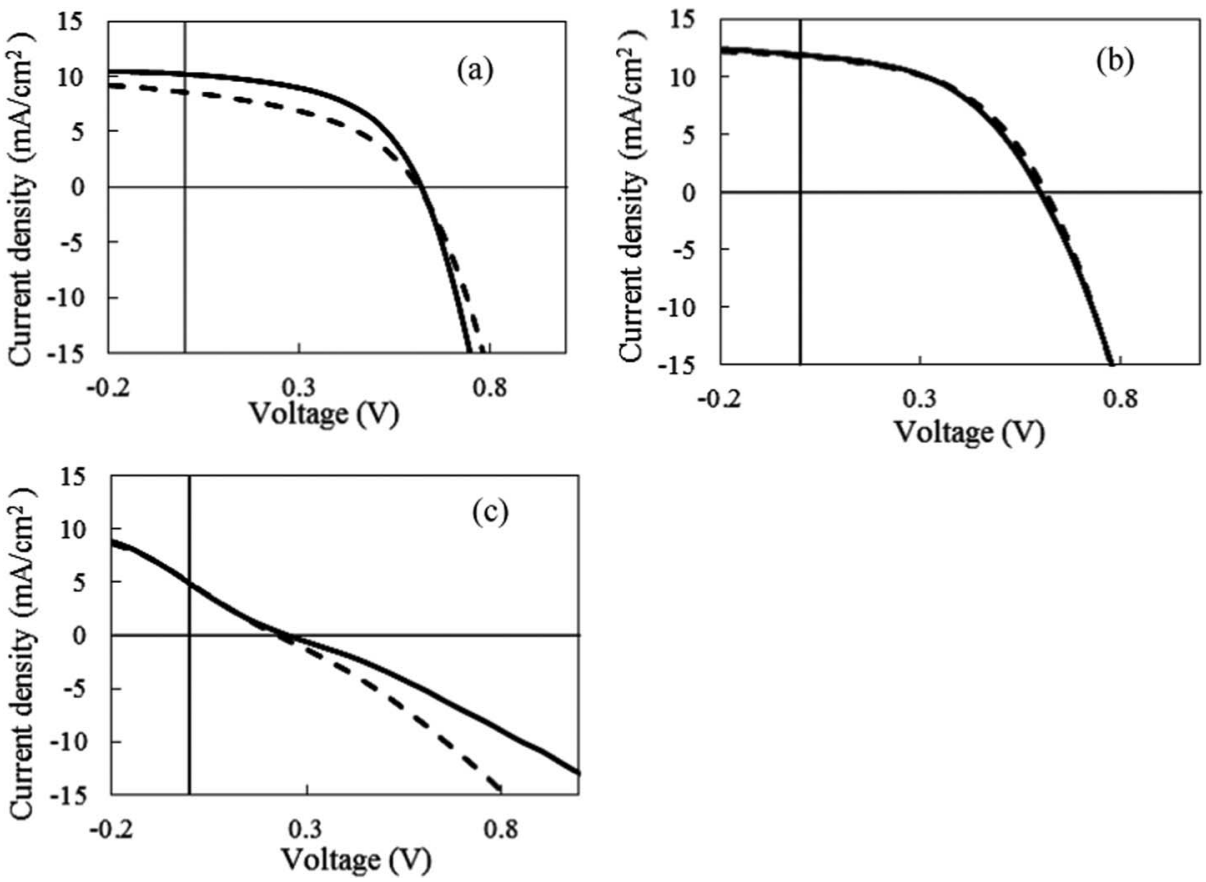

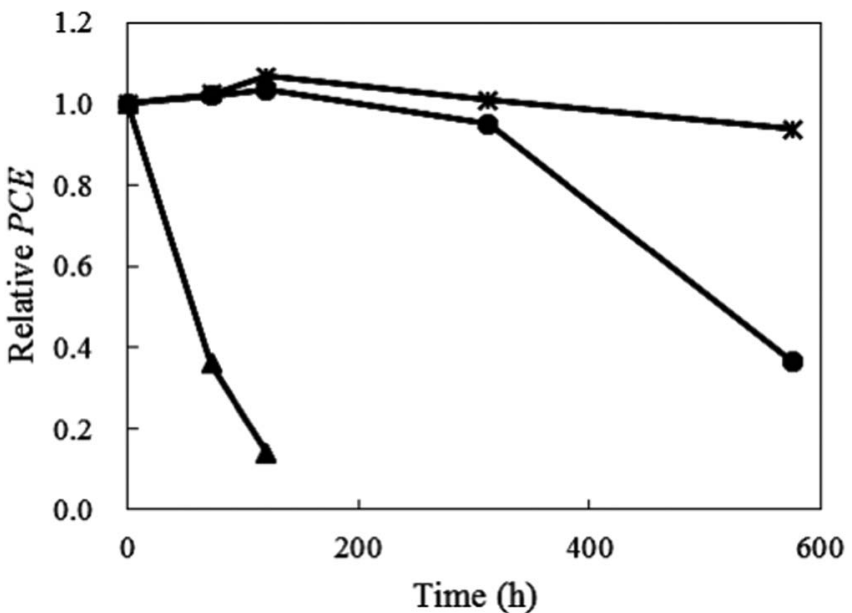

Figure 2. Time-course changes of relative $P C E$ of the hybrid cells composed of glass-ITO/TiO $2 / \mathrm{Sb}_{2} \mathrm{~S}_{3} / \mathrm{HTL}$ [HTL $=\mathrm{P} 3 \mathrm{HT} / \mathrm{PEDOT}$ : PSS (triangle), $\mathrm{ZnPc}$ (cross), or $\mathrm{MoO}_{3}$ (circle)]/Au with UV cut filter at $63^{\circ} \mathrm{C}$ and $50 \% \mathrm{RH}$ under 1 sun. no irradiation of light. This result is probably ascribed to the acidic property of the diluted PEDOT:PSS solution, which tends to lower the cell performance. ${ }^{25,26}$ On the contrary, there was no lowering the $P C E$ s after $1 \mathrm{~d}$ at $63^{\circ} \mathrm{C}$ and $50 \% \mathrm{RH}$ in the dark both in the cases of $\mathrm{ZnPc}$ and $\mathrm{MoO}_{3}$.

Effect of hole transporting layers (HTLs) on stability.-The durability test of the cells with UV cut filter was performed at $63^{\circ} \mathrm{C}$ and $50 \% \mathrm{RH}$ under 1 sun as shown in Figure 2. PCE of P3HT/PEDOT:PSS decreased to the relative value of $10 \%$ after $100 \mathrm{~h}$ photo-irradiation. On the other hand, in the cases of $\mathrm{ZnPc}$ and $\mathrm{MoO}_{3}, P C E$ s kept constant until $300 \mathrm{~h}$ irradiation. However, that of $\mathrm{MoO}_{3}$ started to decrease gradually after $300 \mathrm{~h}$, while $\mathrm{ZnPc}$ indicated stable and $90 \%$ of $P C E$ was retained after $500 \mathrm{~h}$. TEM-EDX observations of the cross-sectional views of glass-ITO/TiO ${ }_{2} / \mathrm{Sb}_{2} \mathrm{~S}_{3} /$ $\mathrm{MoO}_{3} / \mathrm{Au}$ before and after the durability test for $576 \mathrm{~h}$ revealed that $\mathrm{Sb}$ and Mo diffused opposite directions one another (Figure 3). These diffusions during the durability test might affect the lowering of PCEs.

Effect of electron transporting layers (ETLs) on stability.-Two ETLs were utilized and compared in terms of durability for the
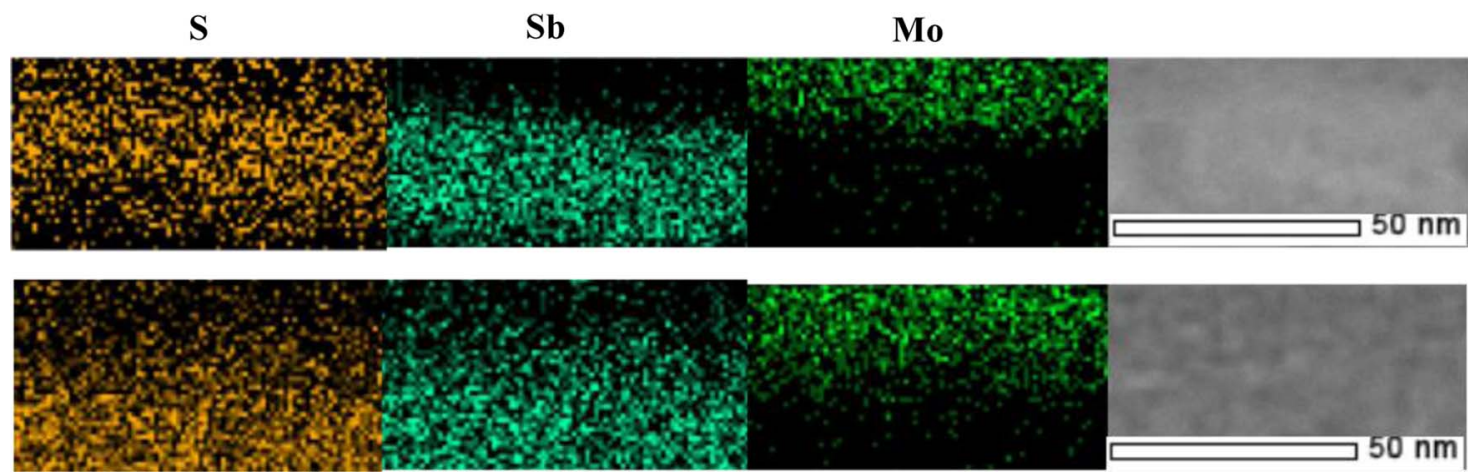

Figure 3. Cross sectional TEM images (right) and EDX images of $\mathrm{S}$, $\mathrm{Sb}$, and Mo elemental maps (left 3 ) of $\mathrm{Sb}_{2} \mathrm{~S}_{3} / \mathrm{MoO}_{3}$ layers of the hybrid solar cells composed of glass-ITO/TiO $/ \mathrm{Sb}_{2} \mathrm{~S}_{3} / \mathrm{MoO}_{3} / \mathrm{Au}$ fresh after preparation (above), and after $576 \mathrm{~h}$ under 1 sun at $63^{\circ} \mathrm{C}$ and $50 \% \mathrm{RH}$ (below). The thin film samples for the observations were prepared by FIB method after carbon coating and TEM and EDX have been operated with JEOL JEM-2010FEF at $200 \mathrm{kV}$. 

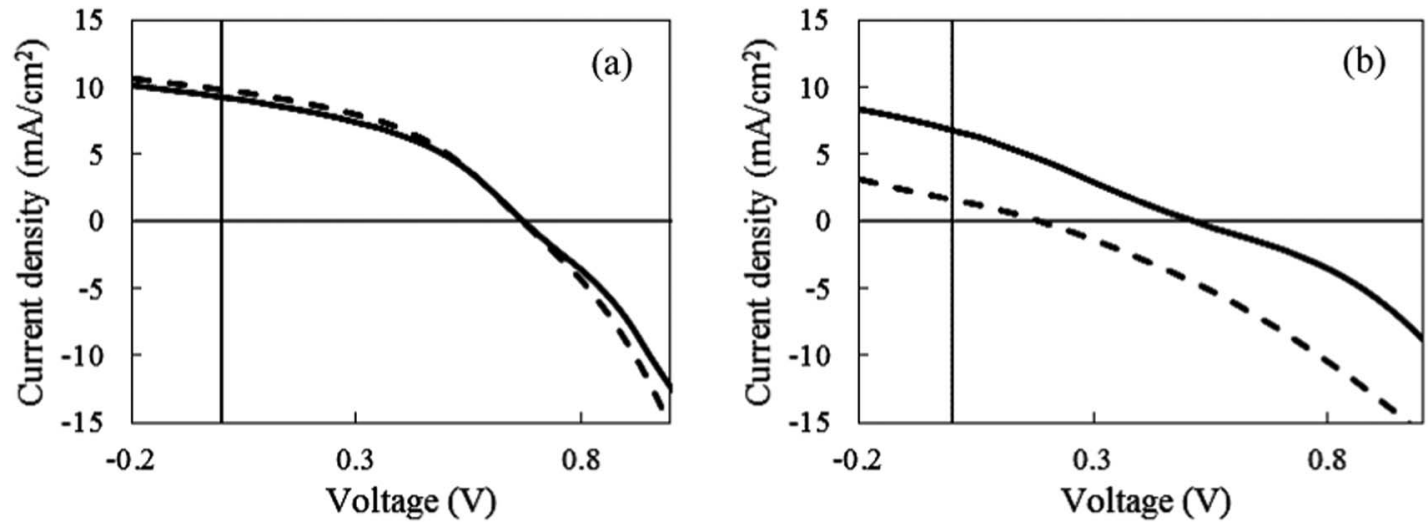

Figure 4. $J-V$ curves of (a) glass-ITO/TiO $2 / \mathrm{Sb}_{2} \mathrm{~S}_{3} / \mathrm{ZnPc} / \mathrm{Au}$, (b) glass-ITO/ZnO/Sb $2 \mathrm{~S}_{3} / \mathrm{ZnPc} / \mathrm{Au}$ fresh after preparation (solid), and after $7 \mathrm{~d}$ at $63{ }^{\circ} \mathrm{C}$ and $50 \%$ RH under 1 sun (broken).

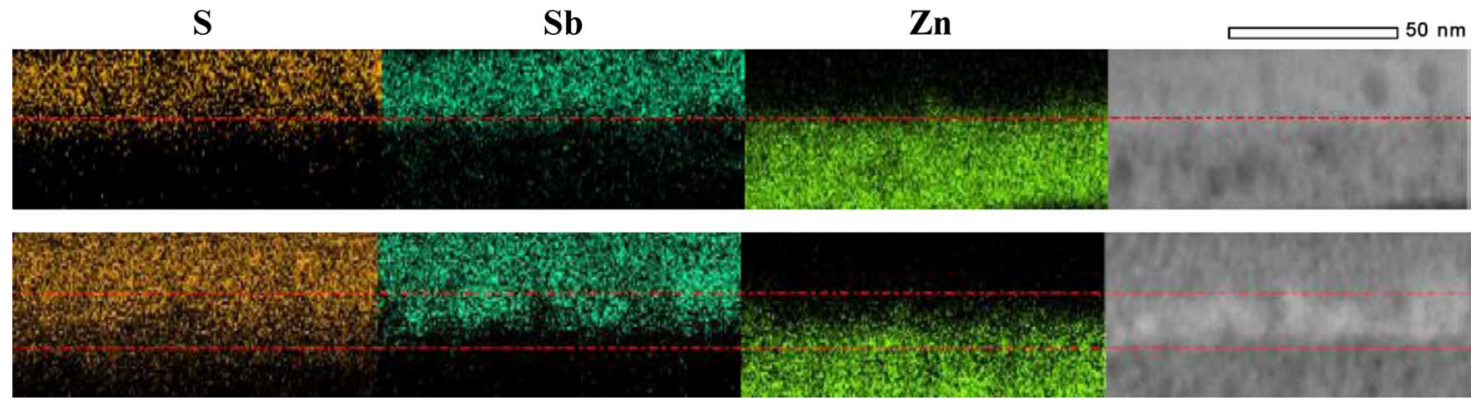

Figure 5. Cross sectional TEM images (right) and EDX images of S, Sb, and $\mathrm{Zn}$ elemental maps (left 3) of $\mathrm{ZnO} / \mathrm{Sb}_{2} \mathrm{~S}_{3}$ layers of the hybrid solar cells composed of glass-ITO/ZnO/Sb $\mathrm{S}_{3} / \mathrm{ZnPc} / \mathrm{Au}$ fresh after preparation (above), and after $7 \mathrm{~d}$ at $63^{\circ} \mathrm{C}$ and $50 \% \mathrm{RH}$ under 1 sun (below). The thin film samples for the observations were prepared by FIB method after carbon coating and TEM and EDX have been operated with JEOL JEM-2010FEF at $200 \mathrm{kV}$.

$\mathrm{Sb}_{2} \mathrm{~S}_{3}$-based hybrid solar cells with $\mathrm{TiO}_{2}$ or $\mathrm{ZnO}$ nanoparticles as glass-ITO/TiO $2 / \mathrm{Sb}_{2} \mathrm{~S}_{3} / \mathrm{ZnPC} / \mathrm{Au}$ or glass-ITO/ZnO/Sb $2 \mathrm{~S}_{3} / \mathrm{ZnPC} / \mathrm{Au}$ with UV cut filter at $63^{\circ} \mathrm{C}$ and $50 \% \mathrm{RH}$ under 1 sun. The $J-V$ curves of the initial photovoltaic performance and after $7 \mathrm{~d}$ and the timecourse changes of relative PCEs through the durability test (Figure 4) indicate that almost constant stability of $\mathrm{TiO}_{2}$-based cell and remarkable lowering of the $P C E$ and lability of $\mathrm{ZnO}$-based one. In particular, the fill factor $(F F)$ and the series resistance $\left(R_{s}\right)$ of glassITO/TiO ${ }_{2} / \mathrm{Sb}_{2} \mathrm{~S}_{3} / \mathrm{ZnPC} / \mathrm{Au}$ had been improved as $F F$ from 0.415 to

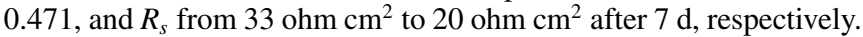
Therefore, using $\mathrm{TiO}_{2}$ is effective to adjust the interface of the device under the conditions with $\mathrm{UV}$ cut filter at $63^{\circ} \mathrm{C}$ and $50 \% \mathrm{RH}$ under 1 sun. On the other hand, it was found by TEM-EDX observations of the cross-sectional views of glass-ITO/ZnO/Sb $\mathrm{S}_{3} / \mathrm{ZnPC} / \mathrm{Au}$ (Figure 5) that initial distribution of $\mathrm{S}$ was well-corresponding with that of $\mathrm{Sb}$, however, $\mathrm{S}$ diffused wider than $\mathrm{Sb}$ and migrated toward $\mathrm{Zn}$ after the durability test and presumably substitution of $\mathrm{S}$ of $\mathrm{Sb}_{2} \mathrm{~S}_{3}$ for $\mathrm{O}$ of $\mathrm{ZnO}$ might occur and result in the formation of $\mathrm{ZnS}$.

Effect of $\boldsymbol{U V}$ light irradiation on stability.-In order to investigate the effect of UV light irradiation, another durability test of glass-ITO/ $\mathrm{TiO}_{2} / \mathrm{Sb}_{2} \mathrm{~S}_{3} / \mathrm{ZnPC} / \mathrm{Au}$ without UV cut filter was performed at $63^{\circ} \mathrm{C}$ and $50 \% \mathrm{RH}$ under 1 sun. The $J-V$ curves of the initial photovoltaic performance (solid) and after $3 \mathrm{~d}$ (broken) were indicated in Figure 6. The relative PCE of $90 \%$ was retained for $1,500 \mathrm{~h}$ with UV cut filter, however the photovoltaic ability has almost been lost without the cut filter after $72 \mathrm{~h}$. Decolorization was observed after the irradiation without the UV cut filter though the decolorization did not occur with the filter. Once the $\mathrm{TiO}_{2}$ layer was removed from the cell, described as glass-ITO/Sb $\mathrm{S}_{3} / \mathrm{ZnPC} / \mathrm{Au}$, there was no decolorization even when without using the UV cut filter. In this context, anatase
$\mathrm{TiO}_{2}$ nanoparticles in this case act as the photocatalyst during the UV light irradiation ${ }^{27}$ to oxidize and decompose $\mathrm{Sb}_{2} \mathrm{~S}_{3}$, which resulted in the above decolorization of the cells. TEM-EDX observations of the cross-sectional views of colored (being not decolorized) site and decolorized site (Figure 7) indicated that the existence of $\mathrm{S}$ and $\mathrm{O}$ was confirmed at the colored site though only $\mathrm{O}$ was confirmed (viz.

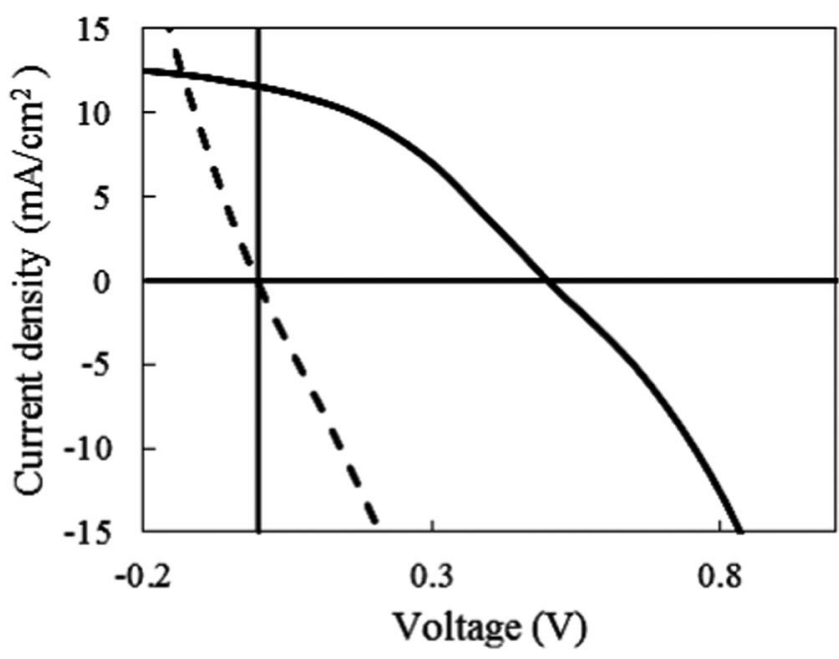

Figure 6. $J-V$ curves of glass-ITO/TiO ter fresh after preparation (solid) and after $3 \mathrm{~d}$ storage at $63^{\circ} \mathrm{C}$ and $50 \% \mathrm{RH}$ under 1 sun (broken). 


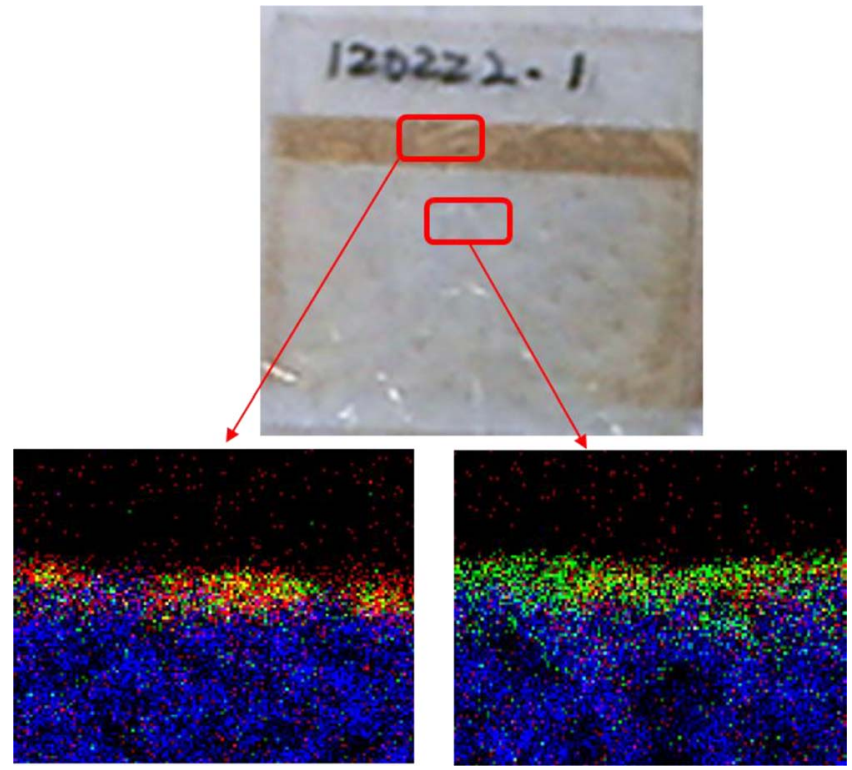

Figure 7. Cross sectional EDX images of $\mathrm{S}$ (red), $\mathrm{Sb}$ (green), and Ti (blue) elemental maps of colored site (left) and decolorized site (right) of ITO/TiO ${ }_{2}$ $\mathrm{Sb}_{2} \mathrm{~S}_{3}$ layers of the hybrid solar cells composed of glass-ITO/TiO $/$ $\mathrm{Sb}_{2} \mathrm{~S}_{3} / \mathrm{ZnPc} / \mathrm{Au}$ without $\mathrm{UV}$ cut filter after $1 \mathrm{~d}$ at $63^{\circ} \mathrm{C}$ and $50 \% \mathrm{RH}$ under 1 sun.

$\mathrm{S}$ was not detected) at the decolorized site. This is also supporting the oxidative decomposition of $\mathrm{Sb}_{2} \mathrm{~S}_{3}$ by photoactivated $\mathrm{TiO}_{2}$.

\section{Summary}

We prepared $\mathrm{Sb}_{2} \mathrm{~S}_{3}$-based solar cells with ETL of $\mathrm{TiO}_{2}$ or $\mathrm{ZnO}$ in addition to HTL of P3HT/PEDOT: PSS, $\mathrm{ZnPc}$, or $\mathrm{MoO}_{3}$ and compared their photovoltaic performance in terms of durability with encapsulation by using glass and UV cutoff films. Combination with $\mathrm{ZnPc}$ and $\mathrm{TiO}_{2}$ has the highest durability with retaining the relative $P C E$ of $90 \%$ under the conditions of 1 sun at $63^{\circ} \mathrm{C}$ at a relative humidity of $50 \%$ for $1,500 \mathrm{~h}$. Effective suppression of the photoactivation of $\mathrm{TiO}_{2}$ through UV light irradiation by using cut filter is essential to realize the long term stability and promising further extension for optimization of the photovoltaic performance.

\section{Acknowledgments}

This research was partially supported by The Ministry of Education, Culture, Sports, Science and Technology.

\section{References}

1. J. A. Chang, J. H. Rhee, S. H. Im, Y. H. Lee, H. J. Kim, S. I. Seok, M. K. Nazeeruddin, and M. Graetzel, Nano Lett., 10, 2609 (2010).

2. S. H. Im, C. S. Lim, J. A. Chang, Y. H. Lee, N. Maiti, H. J. Kim, M. K. Nazeeruddin, M. Graetzel, and S. I. Seok, Nano Lett., 11, 4789 (2011).

3. J. H. Heo, S. H. Im, J. Kim, P. P. Boix, S. J. Lee, S. I. Seok, I. M. Seo, and J. Bisquert, J. Phys. Chem. C, 116, 20717 (2012).

4. Y. C. Choi, D. U. Lee, J. H. Noh, E. K. Kim, and S. I. Seok, Adv. Funct. Mater, 24, 3587 (2014).

5. N. Guijarro, T. Lutz, T. Lana-Villarreal, F. O'Mahony, R. Gomez, and S. A. Haque, J. Phys. Chem. Lett., 3, 1351 (2012).

6. H. Wang, T. Kubo, J. Nakazaki, T. Kinoshita, and H. Segawa, J. Phys. Chem. Lett., 4, 2455 (2013).

7. P. K. Santra and P. V. Kamat, J. Am. Chem. Soc., 134, 2508 (2012)

8. A. Kojima, K. Teshima, Y. Shirai, and T. Miyasaka, J. Am. Chem. Soc., 131, 6050 (2009).

9. M. M. Lee, J. Teuscher, T. Miyasaka, T. N. Murakami, and H. J. Snaith, Science, 338, 643 (2012).

10. W. S. Yang, J. H. Noh, N. J. Jeon, Y. C. Kim, S. Ryu, J. Seo, and S. I. Seok, Science, 348, 1234 (2015).

11. E. L. Gui, A. M. Kang, S. S. Pramana, N. Yantara, N. Mathews, and S. Mhaisalkar, J. Electrochem. Soc., 159, B247 (2012).

12. D. H. Kim, S. J. Lee, M. S. Park, J. K. Kang, J. H. Heo, S. H. Im, and S. J. Sung, Nanoscale, 6, 14549 (2014).

13. Y. C. Choi and S. I. Seok, Adv. Funct. Mater, 25, 2892 (2015).

14. R. Gonzalez-Lua, J. Escorcia-Garcia, D. Perez-Martinez, M. T. S. Nair, J. Campos, and P. K. Nair, ECS J. Solid State Sci. Technol., 4, Q9 (2015).

15. C. P. Liu, Z. H. Chen, H. E. Wang, S. K. Jha, W. J. Zhang, I. Bello, and J. A. Zapien, Appl. Phys. Lett., 100, 243102 (2012).

16. T. Oku, T. Yamada, K. Fujimoto, and T. Akiyama, Coatings, 4, 203 (2014).

17. S. Panigrahi, T. Calmeiro, R. Martins, D. Nunes, and E. Fortunato, ACS Nano, 10, 6139 (2016).

18. T. Minami, Y. Nishi, and T. Miyata, Appl. Phys. Express, 9, 052301/1-052301/4 (2016).

19. A. Kay and M. Graetzel, Chem. Mater, 14, 2930 (2002).

20. S. J. Moon, Y. Itzhaik, J. H. Yum, S. M. Zakeeruddin, G. Hodes, and M. Graetzel, J. Phys. Chem. Lett., 1, 1524 (2010).

21. K. Tsujimoto, D. C. Nguyen, S. Ito, H. Nishino, H. Matsuyoshi, A. Konno, G. R. A. Kumara, and K. Tennakone, J. Phys. Chem. C, 116, 13465 (2012).

22. J. H. Li, J. Huang, and Y. Yang, Appl. Phys. Lett. 90, 173505 (2007).

23. A. S. Subbiah, A. Halder, S. Ghosh, N. Mahuli, G. Hodes, and S. K. Sarkar, J. Phys. Chem. Lett. 5, (2014).

24. W. J. E. Beek, M. M. Wienk, M. Kemerink, X. Yang, and R. A. J. Janssen, J. Phys. Chem. B, 109, 9505 (2005).

25. O. Synooka, F. Kretschmer, M. D. Hager, M. Himmerlich, S. Krischok, D. Gehrig, F. Laquai, U. S. Schubert, G. Gobsch, and H. Hoppe, ACS Appl. Mater. Interfaces, $\mathbf{6}$, 11068 (2014).

26. B. Roth, G. A. R. Benatto, M. Corazza, R. R. Sondergaard, S. A. Gevorgyan, M. Jorgensen, and F. C. Krebs, Adv. Energy Mater, 5, 1401912/1 (2015).

27. X. Wang, Z. Li, J. Shi, and Y. Yu, Chem. Rev., 114, 9346 (2014). 